IRA-International Journal of Management \& Social Sciences

ISSN 2455-2267; Vol.04, Issue 01 (2016)

Institute of Research Advances

http://research-advances.org/index.php/RAJMSS

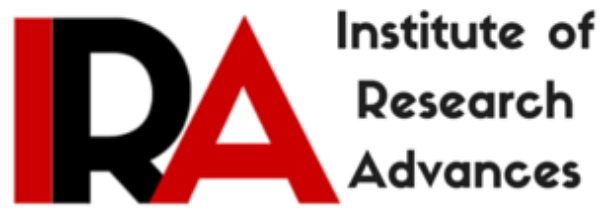

\title{
Organizational Commitment of Para-Medical Staff with reference to Marital Status
}

\author{
Dr. Mrinali Tikare \\ GNVS Institute of Management \\ Sion- Mumbai, \\ India.
}

DOI: http://dx.doi.org/10.21013/jmss.v4.n1.p1

\section{How to cite this paper:}

Tikare, M. (2016). Organizational Commitment of Para-Medical Staff with reference to Marital Status. IRA-International Journal of Management \& Social Sciences (ISSN 2455-2267), 4(1). doi:http://dx.doi.org/10.21013/jmss.v4.n1.p1

(C) Institute of Research Advances

(c) EY-NC

This works is licensed under a Creative Commons Attribution-Non Commercial 4.0 International License subject to proper citation to the publication source of the work.

Disclaimer: The scholarly papers as reviewed and published by the Institute of Research Advances (IRA) are the views and opinions of their respective authors and are not the views or opinions of the IRA. The IRA disclaims of any harm or loss caused due to the published content to any party. 


\section{ABSTRACT}

The commitment of Para-medical employees contributes significantly to the success of hospital organization. The present study attempts to analyze an organizational commitment marital status of Para-medical employees. The data have been collected from eight cities, comprising of four zones of India. The study uses a stratified sampling method in which 219 Para-medical employees from 32 hospitals have responded. This study uses the well known instrument - ACN scale developed by Allen and Meyer (1997).

The result indicated that there is no significant difference in total score of commitment, affective commitment, continuance commitment and normative commitment with reference to marital status. The reasons have been discussed subsequently.

Keywords: Para-medical staff, India, Organizational Commitment, Hospitals, Marital Status

\subsection{Introduction}

Healthcare has become one of India's largest sectors - both in terms of revenue and employment. The Indian healthcare industry is growing at a tremendous pace due to its strengthening coverage, services and increasing expenditure by public as well private players. India's primary competitive advantage lies in its large pool of well-trained medical professionals. Also, India's cost advantage compared to peers in Asia and Western countries is significant - the cost of surgery in India is one-tenth of that in the US or Western Europe. India requires 600,000 to 700,000 additional beds over the next five to six years. (IBEF Report 2015).

In healthcare business apart from doctors and nursing staff, there is one core group working very sincerely behind the veil and never hogging the limelight like the former. This group comprises of pathology technicians, radiology technicians, pharmacist and many more who mainly are labelled as 'Para-medical Staff'. The job of this group is most important as the entire performance of doctor's medical treatment is dependent on accuracy in reporting done by the para-medical staff. For effective delivery of healthcare to patients, the role of para-medical staff is crucial. This silent group should be continuously well motivated intrinsically and extrinsically. The commitment of this group contributes significantly to the success of hospital organization.

Marriage, also called matrimony or wedlock, is a socially or ritually recognized union or legal contract between spouses that establishes rights and obligations between them, between them and their children, and between them and their in-laws. Marriage and established family life are the unique qualities of a human being Azeez A.E.P. (2013), which makes them to be an integral element of social life. Marriage as an institution has a crucial role in helping two individuals to have personal growth and enrichment from established family life. Marriage is a commitment with love and responsibility for peace, happiness and development of strong family relationships Philip O. A. \& Okai U. M. (2015). Marital adjustment calls for a maturity that accepts and understands growth and development in the spouse. Individuals may marry for several reasons, including legal, social, libidinal, emotional, financial, spiritual, and religious purposes.

\subsection{Organizational Commitment (OC)}

Employee commitment towards an organization has been defined in a variety of ways including (1) an attitude or an orientation that links the identity of the person to the organization, (2) a process by which the goals of the organization and those of the individual become congruent, (3) an involvement with a particular organization, (4) the perceived rewards associated with continued participation in an 
organization, (5) the costs associated with leaving, and (6) normative pressures to act in a way that meets organizational goals (Tikare M.,2015). However, the adopted operational definition of this study is provided by Meyer and Allen (1991). According to this definition, organizational commitment is, "a psychological state that characterizes the employee's relationship with the organization, and has implications for the decision to continue membership in the organization."

\subsection{Construct - Organizational Commitment}

An employee's liking for an organization is termed affective commitment and includes identification with and involvement in the organization. Employees with a strong affective commitment continue in employment with the organization because they want to do so. Continuance commitment refers to an awareness of the costs associated with leaving the organization. Employees whose primary link to the organization is based on continuance commitment remain with their employer because they need to do so. Finally, normative commitment reflects a feeling of obligation to continue employment. Employees with a high level of normative commitment feel that they ought to remain with the organization (Meyer \& Allen, 1997).

\subsection{Benefits of Organizational Commitment}

Extant literature (Tikare M., 2015) observed that advantages of 'employees with high commitment' like work devotion with great energy, better work performance, better adaption with change, high work satisfaction, high productivity, employee exhibit stability, employee accomplish organizational goals, accepts organizational demands, task completion, best quality production, addresses service recovery, participate in professional development, reduction in employee turnover, reduction in employee absenteeism (Steers, 1977; Porter et al., 1974; Reiches, 1985; Larkey \& Morrill, 1995; Paré et al., 2001; Etzioni, 1975; Mowdays et al., 1974; Rod M. \& Nicholas J. A.,2010; Randall, 1987).

\subsection{Review of Literature}

The literature review is an attempt to offer insights into the factors that constitute an organizational commitment. The review of literature builds a causal linkage between the marital status of the employee and organizational commitment.

\subsection{Studies related to Marital Status and organizational commitment}

Generally, an individual's marital status can be divided into three categories - Married employees, Unmarried Employees, and Single parents. Taiuwo (2003) found that there is a positive relationship between organizational commitment and marital status. In the view of Chughtai \& Zafar (2006), marital status has emerged as a consistent predictor of organizational commitment. Kalenberg et al. (1995), in their study of dentists, found that marriage is related to commitment. However, this relationship was only significant for behavioral commitment among males.

Married people have more family responsibilities and need more stability and security in their jobs, and therefore, they are likely to be more committed to their current organization than their unmarried counterparts. Sikorska-Simmons (2005) suggested that married individuals have a greater commitment to their organizations. The studies conducted by Hrebiniak \& Alutto (1972) and John \& Taylor (1999) indicated that married people were more committed to their organization than unmarried people. The study of Kacmar et al. (1999); Mathieu \& Zajac (1990) also corroborated that married individuals report higher levels of commitment than unmarried individuals because of their greater financial burdens and family responsibilities. Bowen et al. (1994) who found that married workers were more committed to the 
organization than single workers. An explanation for this finding might be that married workers rather than single workers have more family responsibilities to cater for that require financial support and as such, they are more committed to the organization.

In the discussion of marriage and organizational commitment, even employees' parental status has outstanding effects on work-family conflict (Bragger et al., 2005; Catalyst, 1996; 2003). According to many studies, parents' experience more work-family conflict than those couples not having children and the reason is children requires disciplined time allocation. The results of Aggarwal \& Khandelwal (2009) depicted that there is a significant difference between married and unmarried employees. They provided the rationale that since marriage increases the responsibility of one's family, off-the-job commitment and loyalty (to one's spouse and children) finds itself difficult to translate in on-the-job commitment and loyalty. Research has documented a spill over effect between what happens at work and home (Zedeck and Mosier, 1990) and that quality of one's life, in general, can rub off on a person's work life (Katzell \& Thompson, 1990).

The study conducted by Santhana K. L. et al. (2012) in Chennai recognized that employed married women undertake multiple roles and work life balance become a challenge. Marital status majorly affects female employees as described by Corcoran et al. (1984) and Felmlee (1995). It is more probable for mothers rather than fathers to change jobs, work part time or quit working when the family responsibilities increase because families generally cannot risk losing the income of the father, as it is generally higher.

By using Chi-square test, Maini V. (2001) showed that there is a significant negative relationship between marital status and job commitment. This implies that commitment to one's job may be more if one is single. Clearly, marriage brings additional responsibilities of home management and child rearing which negatively affect the job commitment of a woman. Although Hrebiniak \& Alutto (1972) observed that separated individuals, especially women, have more commitment level as they see higher costs attached to leaving an organization.

To justify the negative relationship of marital status and commitment Kapur P. (1975) stated, "to be successful in marriage, a woman is required to be submissive, whereas to be successful in a job, a woman is required to be assertive." Thus, expectations in these roles are contradictory, and so a negative relationship exists between them. These findings agree with Fogarty (1971) that the expectations from a woman as a wife and mother are very different from those as an executive. In the study of nurses, Cherniss (1991) and Korabik \& Rosin (1996) found that there is no association between marital status and occupational commitment.

Marital status incorporated factors like family responsibility, time allocation to children, financial burden, and contradictory roles in the workplace and the home. Married people need stability and security in their jobs. In the light of these findings and explanation, the question arises, which status group of Para-Medical staff is more committed in hospital organization in India? Therefore, this study hypothesizes that -

Null Hypothesis (Ho): There is no significant difference in the total organizational commitment level score with reference to Marital Status.

\subsection{Research Methodology}

This part outlines the detailed methodology followed in the research. 


\subsection{Significance of the Study}

There are three ways in which this study added to the collective research literature: (a) it provides insight of organizational commitment of Para-Medics; (b) it may assist healthcare sectors in retaining, satisfying Para-Medical employees by enhancing the commitment level; (c) and it generated data that may be used to develop a model to prompt further research.

\subsection{Objectives of the Research}

The paper has three objectives, such as:

1. To find out the commitment level of Para-Medical employees towards their hospital organization.

2. To identify the differences in the commitment level of married and unmarried Indian Para-Medics.

3. To make suggestions to hospitals to build a committed workforce.

\subsection{Hypotheses of the Study}

In the view of literature, the following null hypotheses can be proposed:

Table No. 1: Hypotheses

\begin{tabular}{|c|l|}
\hline SR. NO. & \multicolumn{1}{c|}{ HYPOTHESES } \\
\hline 3.3.a & $\begin{array}{l}\text { There is no significant difference in the mean affective commitment level scores of } \\
\text { Para-Medical staff with reference to Marital Status. }\end{array}$ \\
\hline 3.3.b & $\begin{array}{l}\text { There is no significant difference in the mean continuance commitment level scores of } \\
\text { Para-Medical with reference to Marital Status. }\end{array}$ \\
\hline 3.3.c & $\begin{array}{l}\text { There is no significant difference in the mean normative commitment level scores of } \\
\text { Para-Medical with reference to Marital Status. }\end{array}$ \\
\hline 3.3.d & $\begin{array}{l}\text { There is no significant difference in the mean total organizational commitment level scores } \\
\text { of Para-Medical with reference to Marital Status. }\end{array}$ \\
\hline
\end{tabular}

Source: Primary Work

\subsection{Research Process}

The study has undertaken by adopting the following process- 
Table No. 2: Research Process

\begin{tabular}{|c|c|c|c|c|}
\hline Epistemology & Theoretical & Methodology & Methods & Analysis \\
\hline Objectivism & Positivism & $\begin{array}{c}\text { Survey } \\
\text { Research }\end{array}$ & $\begin{array}{l}\bullet \text { Sampling } \\
\text { Questionnaire }\end{array}$ & $\begin{array}{c}\text { Statistical } \\
\text { analysis }\end{array}$ \\
\hline
\end{tabular}

Source: Primary Work

This research study has been designed to be deductive in nature and reflects an objective inquiry. The study seeks to present an acceptable notion of the differences among commitment level of the Para-Medics with reference to marital status. The epistemology of the study has taken a positivist stance, and the phenomenon is explained with empiricism and logical reasoning by using quantitative data (Tikare M., 2015).

\subsection{Scope of the Study}

The data were collected from four zones and eight cities of India representing 32 hospitals. All these hospitals are either trust hospitals or private hospitals and have more than 50 bedded capacities. The focus of the study is on Para-Medical employees working in the hospitals. However, the discussion regarding 'Gender', 'Occupational Commitment', kept out of the scope of this study.

The Para-Medical Staff is defined as 'A person trained to assist medical professionals and to give emergency medical treatment' (thefreedictionary.com).

The operational definition of marital status is, 'The marital status is the civil status of each individual in relation to the marriage laws or customs of the country, i.e. never married, married, widowed and not remarried, divorced and not remarried, married but legally separated, de-facto union (stats.oecd.org). However, with reference to Indian Para-Medics, this study has made only two groups, i.e. Married and Unmarried.

\subsection{Data collection}

To conduct this study, 400 questionnaires were distributed among the Para-Medical staff. This study was conducted during May 2011 -March 2013. But after the completion of the survey, only 300 Para-Medics gave their responses, out of which only 219 questionnaires were included in this study. As a result, the response rate was 55\%. During this study, the following sampling techniques were used.

Table No.3: Techniques Used In Sampling

\begin{tabular}{|c|c|c|}
\hline Selection Elements & Techniques Used & Basis \\
\hline Selection of Zones & Stratification & $\begin{array}{l}\text { Based on- } \\
\qquad \begin{array}{l}\text { - Study of V. K. Chadha et al. (2003) } \\
\text { - National Employability Report } 2013\end{array}\end{array}$ \\
\hline
\end{tabular}




\begin{tabular}{|c|c|c|}
\hline Selection of Eight Cities & Stratification & $\begin{array}{l}\text { Following references used to find out Tier I \& } \\
\text { Tier II cities in India - } \\
\text { - India Urbanization Econometric Model, } \\
\text { McKinsey Report - } 2010 \\
\text { - CARTUS Report } 2010\end{array}$ \\
\hline Selection of Hospitals & $\begin{array}{c}\text { Disproportionate } \\
\text { Stratification }\end{array}$ & $\begin{array}{l}\text { Based on criteria of inclusion- } \\
\qquad \quad \text { Private and Trust hospitals } \\
\text { - More than } 50 \text { beds capacity } \\
\text { However, all government hospitals were } \\
\text { excluded. }\end{array}$ \\
\hline Selection of Employees & Systematic Random & $\begin{array}{l}\text { Criteria: } \\
\qquad \begin{array}{l}\text { Inclusion of Para-Medical staff } \\
\text { - Exclusion of Class IV and other hospital } \\
\text { employees }\end{array}\end{array}$ \\
\hline
\end{tabular}

Source: Primary Work

\subsection{Description of Tools}

It was decided to use a structured survey schedule because the information that needed to be obtained from Para-Medical staff belongs to 32 different hospitals. The structured schedule ensures uniformity and accuracy while administering the schedule (Tikare M., 2015). The survey schedule has two parts. The first part covers demographic profile, i.e. Zone, City, Name of Hospital, Department, Qualification, Total Professional Experience, Age, Marital Status and Monthly Salary. The second part focuses on commitment variables which comprise of Affective Commitment, Continuance Commitment, Normative Commitment. The schedule includes all close-ended items.

\subsubsection{Selection of Tool: Organizational Commitment}

Different scholars have conceptualized the OC construct differently and developed their measures accordingly. Only three measures that were considered standard, repetitively used earlier and previously tested. Out of these three measures, the researcher has selected Meyer and Allen's (1997) scale. The Selection of Tool with appropriate rationale is presented as follows- 
Table No.4: Selection of Tool, its Dimensions with Appropriate Rationale

\begin{tabular}{|c|c|c|c|c|c|}
\hline $\begin{array}{l}\text { SR. } \\
\text { No. }\end{array}$ & $\begin{array}{l}\text { Measures } \\
\text { (Standard) }\end{array}$ & $\begin{array}{c}\text { Developed } \\
\text { by }\end{array}$ & Dimensions & $\begin{array}{l}\text { Selected/ } \\
\text { Not } \\
\text { Selected }\end{array}$ & Rationale \\
\hline 1 & $\begin{array}{l}\text { Organization } \\
\text { Commitment } \\
\text { Questionnaire } \\
\text { (OCQ) }\end{array}$ & $\begin{array}{l}\text { Porter et } \\
\text { al. } \\
\text { (1974) }\end{array}$ & $\begin{array}{l}\text { Loyalty, Value, } \\
\text { Goal } \\
\text { congruency, } \\
\text { Willingness for } \\
\text { Extra-effort }\end{array}$ & $\begin{array}{c}\text { Not } \\
\text { selected }\end{array}$ & $\begin{array}{ll}\text { - } & \text { Quite old } \\
\text { - } & \text { Based on } \\
\text { attitudinal } \\
\text { dimension }\end{array}$ \\
\hline 2 & $\begin{array}{l}\text { British } \\
\text { Organization } \\
\text { Commitment } \\
\text { Scale (BOCS) }\end{array}$ & $\begin{array}{l}\text { Cook and } \\
\text { Wall } \\
\text { (1980) }\end{array}$ & $\begin{array}{l}\text { Identification, } \\
\text { Involvement, } \\
\text { Loyalty }\end{array}$ & $\begin{array}{c}\text { Not } \\
\text { selected }\end{array}$ & $\begin{array}{l}\text { Primarily developed for } \\
\text { the UK blue-collar workers }\end{array}$ \\
\hline 3 & $\begin{array}{l}\text { Three-dimensional } \\
\text { scale (ACS, CCS, } \\
\text { NCS) }\end{array}$ & $\begin{array}{c}\text { Meyer } \\
\text { and Allen } \\
(1991, \\
1997)\end{array}$ & $\begin{array}{l}\text { Affective, } \\
\text { Continuance, } \\
\text { Normative }\end{array}$ & Selected & $\begin{array}{l}\text { 1. Widely used in } \\
\text { research* } \\
\text { 2. Revalidated by } \\
\text { Krishnaveni R. \& } \\
\text { Ramkumar N. } \\
\text { (2008) and } \\
\text { recommended } \\
\text { suitable for future } \\
\text { research in an } \\
\text { Indian context. }\end{array}$ \\
\hline
\end{tabular}

*Dunham et al., 1994; and McGee \& Ford, 1987.

The researcher wanted to use the latest scale which is suitable for the Indian context to shape up the research with finesse. Exploration of the extant literature revealed that Meyer and Allen's scale (ACN) is the most widely used scale (Dunham et al., 1994; McGee \& Ford, 1987). Moreover, Krishnaveni R. \& Ramkumar N. (2008) studied the revalidation of the three-component conceptualization model of Meyer and Allen (1997) in the context of India and recommended that the scale is suitable for future research. Therefore, the researcher has used a ready-made tool developed by Allen and Meyer (1997) as they measured the desired variables, happens to be the most recent and was also found to be suitable in the Indian context. There is a total of 18 items in the scale of which four are reverse edged items (Tikare M.,2015). This was modified in the Indian context as recommended by Krishnaveni R. \& Ramkumar N. (2008).

\subsubsection{Reliability of the Tool}

The test details are depicted below: 
Table No. 5: Reliability of Instrument (ACN)

\begin{tabular}{|c|c|c|}
\hline \multicolumn{1}{|c|}{$\mathbf{N = 1 3 8}$} & Cronbach Alpha & $\begin{array}{c}\text { Cronbach Alpha of earlier* } \\
\text { studies - Range }\end{array}$ \\
\hline Affective Commitment (6 Items) & 0.847 & 0.77 to 0.88 \\
\hline Continuance Commitment (6 Items) & 0.706 & 0.65 to 0.86 \\
\hline Normative Commitment (6 Items) & 0.756 & 0.69 to 0.84 \\
\hline
\end{tabular}

*Allen \& Mayer (1990a); Cohen A. (1996, 99); Cohen and Kirchmeyer (1995); Hackett et al. (1994); Meyer \& Allen (1997); Meyer, Irving \& Allen (1998); Somers \& Birnbaum (1998).

\subsubsection{Validity of the tool}

After assessing the reliability of ACN measure, a factor analysis was conducted. After factor analysis, it was whittled down to 18 items under three components, namely, Affective, Continuance, and Normative Commitment $(\mathrm{ACN})$. The following table indicates the results of factor analysis -

Table No. 6: Validity of Instrument - Factor Analysis

\begin{tabular}{|c|c|c|c|c|c|c|}
\hline $\begin{array}{l}\text { Variables } \\
-\mathrm{N}=\mathbf{2 1 9}\end{array}$ & $\begin{array}{c}\text { KMO } \\
\text { Measures } \\
\text { of } \\
\text { Sampling } \\
\text { Adequacy } \\
\text { With P } \\
\text { Value }\end{array}$ & $\begin{array}{c}\text { No. New } \\
\text { Components }\end{array}$ & $\begin{array}{c}\text { The } \\
\text { Total of } \\
\text { Factor } \\
\text { Loading }\end{array}$ & $\begin{array}{l}\text { Eigen } \\
\text { Values }\end{array}$ & $\begin{array}{c}\text { Total } \\
\text { Variance } \\
\text { Explained }\end{array}$ & New Factors \\
\hline $\begin{array}{l}\text { Affective } \\
\text { Commitment } \\
\text { (6 Items) }\end{array}$ & $\begin{array}{c}0.853 \\
P=0.000\end{array}$ & 1 & 4.525 & 3.422 & 57.032 & $\begin{array}{c}\text { Affective } \\
\text { Commitment }\end{array}$ \\
\hline $\begin{array}{l}\text { Continuance } \\
\text { Commitment } \\
\text { (6 Items) }\end{array}$ & $\begin{array}{c}0.696 \\
P=0.000\end{array}$ & 1 & 3.794 & 2.448 & 40.793 & $\begin{array}{l}\text { Continuance } \\
\text { Commitment }\end{array}$ \\
\hline $\begin{array}{l}\text { Normative } \\
\text { Commitment } \\
\text { (6 Items) }\end{array}$ & $\begin{array}{c}0.828 \\
P=0.00\end{array}$ & 1 & 3.982 & 2.971 & 49.515 & $\begin{array}{l}\text { Normative } \\
\text { Commitment }\end{array}$ \\
\hline
\end{tabular}

Source: Primary Work 
Extraction Method: Principal Component Analysis.

Based on the generally accepted rules of selecting a factor solution with Eigen values greater than 1 and incremental variance, a three-factor solution was accepted. Finally, the researcher has used the scale of Allen \& Meyer (1997) without making any modifications.

\subsubsection{Scoring Method}

Respondents were asked to reply to each item using a five-point Likert scale format: Strongly agree; agree; neutral; disagree and strongly disagree- as it applies to his or her organizational commitment level. Higher scores indicated a higher level of commitment and lower scores indicates otherwise.

\subsubsection{Interpreting the Score}

The following ranges for the sets of scores provide a quick interpretation of the respondents' scores.

Table No. 7: Range and Interpretation of Measurements

\begin{tabular}{|c|c|c|c|c|c|}
\hline Variables & $\begin{array}{c}\text { No. of } \\
\text { Ouestions }\end{array}$ & $\begin{array}{l}\text { Rating } \\
\text { Scale }\end{array}$ & Range & \multicolumn{2}{|c|}{ Interpretation For Measurement } \\
\hline \multirow{2}{*}{$\begin{array}{c}\text { Affective } \\
\text { Continuance }\end{array}$} & \multirow{3}{*}{$\begin{array}{c}6 \\
\text { (Each) }\end{array}$} & \multirow{3}{*}{1 to 5} & \multirow{3}{*}{6 to 30} & 6.00 to 14.00 & $\begin{array}{l}\text { Lower Level of } \\
\text { Commitment }\end{array}$ \\
\hline & & & & 14.01 to 23.00 & $\begin{array}{l}\text { Moderate Level } \\
\text { of Commitment }\end{array}$ \\
\hline Normative & & & & 23.01 to 30.00 & $\begin{array}{l}\text { High Level of } \\
\text { Commitment }\end{array}$ \\
\hline \multirow{3}{*}{$\begin{array}{c}\text { Total } \\
\text { Organizational } \\
\text { Commitment }\end{array}$} & \multirow{3}{*}{18} & \multirow{3}{*}{1 to 5} & \multirow{3}{*}{18 to 90} & 18.00 to 42.00 & $\begin{array}{l}\text { Lower Level of } \\
\text { Commitment }\end{array}$ \\
\hline & & & & 42.01 to 66.00 & $\begin{array}{l}\text { Moderate Level } \\
\text { of Commitment }\end{array}$ \\
\hline & & & & 66.01 to 90.00 & $\begin{array}{l}\text { High Level of } \\
\text { Commitment }\end{array}$ \\
\hline
\end{tabular}

Source: Primary Work

\subsection{Data Analysis}

The statistical techniques like descriptive techniques and Independent ' $t$ ' Test are used in this study to attain objectives of the study. 


\subsection{Demographic Profile}

This part of the study is focused on details about the demographic profile of respondents from all over India.

Table No. 8: Sample Distribution of Para-Medical Staff

\begin{tabular}{|c|c|c|}
\hline Demographic Profile & \multirow{2}{*}{ Groups } & Frequencies \\
\hline Total $N=219$ & & $\mathbf{N}$ \\
\hline \multirow{4}{*}{ Zone } & East Zone & 79 \\
\hline & North Zone & 57 \\
\hline & South Zone & 45 \\
\hline & West Zone & 38 \\
\hline \multirow{5}{*}{ Age } & Below 21 to 30 Years & 121 \\
\hline & 31 to 40 Years & 65 \\
\hline & 41 to 50 Years & 21 \\
\hline & 51 to 60 Years & 12 \\
\hline & More than 60 Years & 0 \\
\hline \multirow{2}{*}{ Marital Status } & Married & 129 \\
\hline & Unmarried & 90 \\
\hline \multirow{2}{*}{ Gender } & Male & 136 \\
\hline & Female & 83 \\
\hline
\end{tabular}

Source: Primary data

\subsection{Descriptive Analysis of Commitment Variables}

The computation of Total Score, Mean and Standard Deviation is obtained by using SPSS. Table No. 9 shows the division of commitment level in three parameters, i.e. High Level, Moderate Level and Low Level. 
Table No.9: Score, Mean and Standard Deviation

\begin{tabular}{|l|c|c|c|l|}
\hline \multicolumn{1}{|c|}{ Variables of Commitment } & Score & Mean & $\begin{array}{c}\text { Standard } \\
\text { Deviation }\end{array}$ & \multicolumn{1}{c|}{$\begin{array}{c}\text { Measurement of } \\
\text { Level }\end{array}$} \\
\hline Total Commitment & 14692 & $\mathbf{6 7 . 0 8}$ & 9.226 & High Level \\
\hline Affective Commitment & 5380 & $\mathbf{2 4 . 5 7}$ & 3.960 & High Level \\
\hline Continuance Commitment & 4564 & $\mathbf{2 0 . 8 4}$ & 3.564 & Moderate Level \\
\hline Normative Commitment & 4748 & $\mathbf{2 1 . 6 8}$ & 3.856 & Moderate Level \\
\hline
\end{tabular}

Source: Primary Work

From the above table, it is observed that -

- All Para-medical staff showed a high level of total commitment, affective commitment. However, they possess a moderate level of continuance and normative commitment.

\subsection{Testing of Hypotheses}

This part presents testing of hypotheses formulated for the study. The data analysis has been presented.

\subsubsection{Null Hypothesis - Marital Status and Para-Medical Staff}

The following table depicts descriptive statistics and Independent ' $t$ ' Test for commitment level with two groups of marital status. The significance level and retention or rejection of hypotheses also demonstrated with appropriate rationale.

Table No. 10: Descriptive Statistics and Independent ' $t$ ' Test of Commitment with two groups of Marital Status

\begin{tabular}{|c|c|c|c|c|c|}
\hline Marital Status & Married & Unmarried & \multirow{3}{*}{ t Value } & \multirow{3}{*}{$\begin{array}{c}\text { Sig. } \\
\text { p value }\end{array}$} & \multirow{3}{*}{$\begin{array}{c}\text { Significan } \\
/ \\
\text { Not } \\
\text { Significan } \\
\text { (S/NS) }\end{array}$} \\
\hline $\mathrm{N}=219$ & 129 & 90 & & & \\
\hline Variables & $\begin{array}{c}\text { Mean } \\
\text { SD }\end{array}$ & $\begin{array}{c}\text { Mean } \\
\text { SD }\end{array}$ & & & \\
\hline Total Score of Commitment & $\begin{array}{l}67.71 \\
8.18\end{array}$ & $\begin{array}{l}66.08 \\
10.51\end{array}$ & 1.286 & 0.200 & NS \\
\hline
\end{tabular}




\begin{tabular}{|c|c|c|c|c|c|}
\hline Affective Commitment & $\begin{array}{l}24.93 \\
3.721\end{array}$ & $\begin{array}{l}24.03 \\
4.260\end{array}$ & 1.649 & 0.101 & NS \\
\hline Continuance Commitment & $\begin{array}{l}20.95 \\
3.451\end{array}$ & $\begin{array}{l}20.67 \\
3.745\end{array}$ & .567 & 0.572 & NS \\
\hline Normative Commitment & $\begin{array}{l}21.84 \\
3.694\end{array}$ & $\begin{array}{l}21.39 \\
4.063\end{array}$ & .859 & 0.391 & NS \\
\hline
\end{tabular}

Source: Primary Work

\subsubsection{Analysis}

The group of married Para-Medical staff revealed a higher mean for all the variables. However, there is no significant difference between married groups and unmarried groups as ' $p$ ' value is more than 0.05 .

\subsubsection{Findings}

It is observed that there are similarities in the level of organizational commitment between the two groups. Hence, the following Null Hypotheses are retained with reference to Marital Status-

Table No.11: Retention or Rejection of Hypotheses - Marital Status

\begin{tabular}{|c|l|c|}
\hline SR.NO. & \multicolumn{1}{|c|}{ Details of Hypotheses } & Retained/Rejected \\
\hline 3.3.a & $\begin{array}{l}\text { There is no significant difference in the mean affective commitment level } \\
\text { score of Para-Medical Staff with reference to Marital Status. }\end{array}$ & Retained \\
\hline 3.3.b & $\begin{array}{l}\text { There is no significant difference in the mean continuance commitment level } \\
\text { score of Para-Medical Staff with reference to Marital Status. }\end{array}$ & Retained \\
\hline 3.3.c & $\begin{array}{l}\text { There is no significant difference in the mean normative commitment level } \\
\text { score of Para-Medical Staff with reference to Marital Status. }\end{array}$ & Rejected \\
\hline 3.3.d & $\begin{array}{l}\text { There is no significant difference in the mean total commitment level score of } \\
\text { Para-Medical Staff with reference to Marital Status. }\end{array}$ & Retained \\
\hline
\end{tabular}

Source: Primary Work

\subsubsection{Discussion}

The analysis on the basis of two groups of Marital Status described the similarity of the commitment level. The following may be the reason for a similar level of commitment - 
1. In the case of para-medical staff, the married staff is more committed towards organization due to the financial pressures and inherent benefits of healthcare for self and family.

2. Unmarried Staff is more committed due to the opportunity for learning and career advancement.

From the above discussion, it may be concluded that factors like the opportunity for learning, career advancement, and financial pressure affect organizational commitment. The previous research conducted by Maini V. (2001); Kapur P. (1975); Cherniss (1991); Korabik \& Rosin (1996); and their findings associated with the negative relationship between marital status and organizational commitment are not consistent with the findings of the present study.

\subsection{Implication and Recommendation}

The marital status does not interfere if there is a professional role; if there are legal \& ethical and financial responsibilities; and if there is an urge for career advancement.

The following suggestions are proffered to HR Practitioners to build committed workforce in the hospital organization-

A. There should be provisions for Flexi-timings, vacations which may enhance the commitment level of the Para-Medical Staff.

B. There should be an opportunity for learning with advanced technology.

This study has used self-report survey which could be a limiting factor. It is also important to consider that the samples used in this study are Para-Medical Staff, therefore the results of the study cannot be generalized to other industries.

\section{Bibliography}

Abdul Azeez E.P. (2013). Employed Women and Marital Satisfaction: A Study among Female Nurses. International Journal of Management and Social Sciences Research (IJMSSR), 2-11.

Aggarwal, K. \& Khandelwal (2009). Organisational commitment in multinationals: A dynamic interplay among personal, organisational and societal factors. ASBM Journal of Management, II (1).

Allen, N. J. \& Meyer, J. P. (1990a). The Measurement and Antecedents of Affective, Continuance and Normative Commitment to the Organization. Journal of Occupational Psychology, 63(1), 1-18.

Azeez, A.E.P. (2013). Employed Women and Marital Satisfaction: A Study among Female Nurses. International Journal of Management and Social Sciences Research (IJMSSR),2:11.

Blau, G. (1985). The measurement and prediction of career commitment. Journal of Occupational Psychology, 58, 277-288.

Bowen, C.F., Radhakrishna, R. \& Keyser, R. (1994) .Job satisfaction and commitment of 4-H Agents. Journal of Extension, 32, 1-22. 
Bragger, J.D., Rodriguez-Srednicki, O., Kutcher, E.J., Indovino, L. and Rosner, E. (2005). Work-family conflict, work-family culture, and organizational citizenship behaviour among teachers. Journal of Business and Psychology, 20 2, 303-324.

Cherniss, C. (1991). Career commitment in human service professionals: A biographical study. Human Relations, 44(5), 419-437.

Chughtai, A. A. \& Zafar, S. (2006). Antecedents and consequences of organizational commitment among Pakistani university teachers. Applied H.R.M. Research, 11 (1), 39-64.

Chadha, V.K. (2007). Annual Risk Of Tuberculous Infection In Andhra Pradesh, India. Indian J. Tuberculous, 54:177-183.

Clark, L.A. \& Watson, D. (1995). Constructing Validity: Basic issues in objective scale development. Psychological Assessment, 7, (3), 309-319.

Cohen, A. (1991). Career stage as a moderator of the relationship between organisational commitment and is outcome: A meta-analysis. Journal of Occupational Psychology, 64(3), 253-268.

Cohen, A. (1995). Some antecedents of employee commitment and their influence on job performance: A multi-foci study. South African Journal of Business Management, 26(4), 45-135.

Dunham, R., Grube, J., \& Castaneda, M.(1994). Organizational commitment: the utility of an integrative definition. Journal of Applied Psychology, 79, 3, 370-380.

Farooq, N., Irfan, M., \& Farooq, M. (2011). Measurement of the degree of organizational commitment among the faculty members of private sector universities in Peshawar city. Interdisciplinary Journal of Contemporary Research in Business, 3, 4.

Felmlee, D.H. (1995). Causes and consequences of women's employment discontinuity. Work and Occupations, 22, 2, 167-187.

Hashmi H. A. et al., (2007). Marital Adjustment, Stress and Depression among Working and Non-Working Married Women. Internet Journal of Medical. 2(1):19-26.

Hrebiniak, L. G., \& Alutto, J. A. (1972). Personal and role related factors in the development of organizational commitment. Administrative Science Quarterly, 17, 555-572.

Hazarika I. (2013). Health workforce in India: Assessment of availability, production and distribution. WHO South-East Asia J Public Health; 2:106-12.

John, M. C., \& Taylor, W. T (1999). Leadership style, school climate and the institutional commitment of teachers. International Forum (InFo), 2(1), 25-57.

Kacmar, K. M., Carlson, D., \& Brymer, R. A. (1999). Antecedents and consequences of organizational commitment: A comparison of two scales. Educational and Psychological Measurement, 59, 976-994.

Kalenberg, D.O., Becker, B.W. \& Zvonkovic, A. (1995). Work and commitment among young professionals: A study of male and female dentists. Human Relations. 48, (11), 135577. 
Katzell, R. A., \& Thompson, D. E. (1990). Work motivation: Theory and practice. American Psychologist, $45,144-153$.

Korabik, K. \& Rosin, H. (1995). Organizational experiences and propensity to leave: A multivariate investigation of men and women managers. Journal of Vocational Behavior, 46, 1-16.

Krishnaveni, R. \& Ramkumar, N. (2008). Revalidation process for established instruments: A case of Meyer and Allen's organizational commitment scale. ICFAI Journal of Organizational Behavior, 7, 2, 7-17.

Larkey, L., \& Morrill, C. (1995). Organizational commitment as symbolic process. Western Journal of Communication, 59, 193- 212.

Maini, V. (2001). Job commitment of women executives. Management and Labour Studies, 26, 247.

Mathieu, J. E., \& Zajac, D. M. (1990). A review and meta-analysis of the antecedents, correlates and consequences of organizational commitment. Psychological Bulletin, 108, 171-194.

McGee, G. W., Ford, R. C. (1987). Two (or more) dimensions of organizational commitment: Re-examination of the affective and continuance commitment scales. Journal of Applied Psychology, 72, 638-642.

Meyer, J. P. \& Allen, N. J. (1984). Testing the side bet theory of organizational commitment: Some methodological considerations. Journal of Applied Psychology, 69, 372-378.

Meyer, J. P. \& Smith, C.A. (2000) HRM Practices and Organizational Commitment: Test of a Mediation Model. Canadian Journal of Administrative Sciences, 4, 3, 19-33.

Meyer, J. P., \& Herscovitch, L. (2001). Commitment in the workplace: Toward a general model. Human Resource Management Review, 11, 299-326.

Meyer, J. P., \&. Allen, N. J. (1991). A three-component conceptualization of organizational commitment. Human Resource Management Review, 1, 61-89.

Meyer, J. P., Allen, N. J., \& Smith, C. A. (1993). Commitment to organizations and occupations: Extension and test of a three-component conceptualization. Journal of Applied Psychology, 78, 538-551.

Meyer, J. P., Allen, N. J., \&. Gellatly, I. R. (1990). Affective and continuance commitment to the organization: Evaluation of measures and analysis of concurrent and time-lagged relations. Journal of Applied Psychology, 75, 710-720.

Miller M.N \& Mcgowen R.(2000). The Painful Truth: Physicians Are Not Invincible. Southern Medical Journal, 93,10.

Mowday, R. T, Steers, R. M., \& Porter, L. M. (1979). The measurement of organizational commitment. Journal of Vocational Behavior, 14, 224-247.

Mowday, R., Porter, L. \& Steers, R. (1982). Employee organization Linkages: The Psychology of Commitment, Absenteeism, and Turnover. New York: Academic Press. 
Nair, Sreelekha (2007). Rethinking citizenship, community and rights: the case of nurses from Kerala in Delhi. Indian Journal of Gender Studies, 14, 137.

Nandan D., Nair K.S., \& Datta U. (2007). Human Resources For Public Health In India - Issues And Challenges. Health and Population Perspectives and Issues 30 (4): 230-242.

Pare, G., Tremblay, M. \& Lalonde, P. (2001). The role of organizational commitment and citizenship behaviors in understanding relations between human resources practices and turnover intentions of IT personnel. Scientific Series -24, CIRANO, Montreal, Canada.

Philip, O. A. \& Okai, U. M. (2015). Influence of Marital Stressors on Role Performance of Married Academic Women in Tertiary Institutions in Cross River State and Need for Counseling. Journal of Education and Practice, 6:17.

Porter, L. W., Steers, R. M., Mowday, R. T., \& Boulian, P. V. (1974). Organizational commitment, job satisfaction and turnover among psychiatric technicians. Journal of Applied Psychology, 59, 603609.

Priyadarshini, M. S. \& Padmanathan, S. (2012). A study on understanding the levels of job satisfaction, job motivation, organizational commitment, perceived organization support among fresher's and experienced academicians. International Journal of Research in Commerce \& Management, 3, 12.

Randall, D. M. (1987). Commitment and the organization: The organization man revisited. Academy of Management Review, 12, 460-471.

Reichers, A. E. (1985). A review and re-conceptualization of organizational commitment. Academy of Management Review, 10, 465-476.

Rod, M. \& Nicholas, J. A. (2010). Management commitment to service quality and service recovery performance: A study of frontline employees in public and private hospitals. International Journal of Pharmaceutical and Healthcare Marketing, 4, 1, 84-103.

Selmanovic S, Ramic E, Pranjic N, Brekalo-Lazarevic S, Pasic Z, Alic A.(2011). Stress at work and burnout syndrome in hospital doctors. Med Arh (PubMed); 65(4):221-4.

Sharma K. \& Vatsa M. (2011). Domestic Violence against Nurses by their Marital Partners: A Facility-based Study at a Tertiary Care Hospital. Indian J Community Med. 36(3): 222-227.

Siew P.L., Chitpakdee, B., Chontawan, R. (2011). Factors Predicting Organizational Commitment among Nurses in State Hospitals, Malaysia. The International Medical Journal Malaysia, 10 (2).

Sikorska-Simmons E. (2005). Predictors of organizational commitment among staff in assisted living. The Gerontological Society of America. 45, 2, 196-205.

Somers, M.J., \& Birnbaum, D. (1998). Work-related commitment and job performance: It's also the nature of performance that counts. Journal of Organizational Behaviour, 19, 621-634.

Sobecks N.W. , Justice AC, Hinze S., Chirayath H.T., Lasek R.J., Chren M.M., Aucott J., Juknialis B., Fortinsky R., Youngner S., Landefeld C.S. (1999). When doctors marry doctors: a survey exploring the professional and family lives of young physicians. Ann Intern Med., 16;130,312-9. 
Steers, R. M. (1975). Problems in the measurement of organizational effectiveness. Administrative Science Quarterly, 20, $546-558$.

Steers, R. M. (1977). Antecedents and outcomes of organizational commitment. Administrative Science Quarterly, 22, 46-56.

Steers, R. M., \& Rhodes, S. R. (1978). Major influences on employee absenteeism: A process model. Journal of Applied Psychology, 63, 4, 391-407.

Taiuwo, K.O. (As cited in Qureshi, M.I., Saleem, A. M., Salahuddin, H. (2012). Assessment of selected factors on organizational commitment. Gomal University Journal of Research, $28,2$.

Tikare, M. (2015). An Evaluation Of Organizational Commitment Of Indian Nursing Staff Of Trust/Private Hospitals With Reference To Education. Abhinav International Monthly Refereed Journal of Research in Management \& Technology, 4:6.

Zedeck, S., \& Mosier, K. (1990). Work in the family and employee organization. American Psychologist, $45,240-251$.

Books/Reports/Dissertations

Catalyst (1996). Women in corporate leadership. New York: Catalyst.

Catalyst, (2003). Women in US Corporate Leadership. Catalyst, New York.

Corcoran, M., Duncan, G.J. and Ponza, M. (1984). Work experience, job segregation, and wages. Cited from Reskin, B. (Ed.) Sex Segregation in the Workplace, pp. 171-191. Washington, DC: National Academy Press.

Cohen, A. (2003). Multiple commitments in the workplace: An integrative approach. Mahwah, NJ: Lawrence Erlbaum.

Etzioni, A., (1975). A comparative evaluation of complex organization: On power, involvement and their correlates. New Jersey: Free Press.

Fogarty, M.P. \& Rapoport R.N. (1971). Sex career and family. London, George Allen and Unwin Ltd.

Kapur Promilla (1975). The changing status of the working women in India. India: Vikas publishing Pvt. Ltd.

Meyer, J. P. \& Allen, N. J. (1997). Commitment in the Workplace: Theory, Research and Application. Thousand Oaks, Ca: Sage Publications.

Mckinsey Report (2014). India Healthcare.

Porter, L. W., \& Smith, F. J. (1970). The etiology of organizational commitment. Unpublished manuscript, University of California, Irvine. 
Victoria N. (2013). Patient centered hospitals: a study to evaluate the effectiveness of health care delivery in the three selected hospitals in Guntur District, Andhra Pradesh, India. Doctoral dissertation, Acharya Nagarjuna University. 